\title{
International Simone de Beauvoir Society
}

\author{
Nous vous invitons à devenir membre de la Société ou à renouveler votre \\ adhésion pour 2020.
}

Fondée en 1981 et affiliée à la Modern Language Association, l'International Simone de Beauvoir Society est une organisation interdisciplinaire qui parraine des colloques annuels, publie sa propre revue et rassemble un vaste réseau de membres. En plus d'un abonnement individuel gratuit à la revue Simone de Beauvoir Studies, les avantages offerts aux membres incluent la possibilité d'intervenir lors des colloques annuels et de prendre position en rapport à des questions relatives à la Société, l' accès aux nouvelles et aux annonces émises par la Société et l' occasion de prendre part aux activités d'une communauté internationale de chercheur.se.s intéressé.e.s par des sujets touchant la vie, l' œuvre et l' héritage de Simone de Beauvoir. Pour devenir membre de la Société, veuillez consulter la page suivante: beauvoir.weebly.com.

Become a member of the Society or renew your membership for calendar year 2020 .

Formed in 1981 as a Modern Language Association affiliate, the International Simone de Beauvoir Society is an interdisciplinary organization that sponsors yearly conferences, publishes its own journal, and cultivates a wide-ranging member network. Along with a free individual subscription to Simone de Beauvoir Studies, membership benefits include opportunities to present at annual conferences, the ability to vote on Society matters, access to news and announcements, and participation in an international community of scholars interested in topics relevant to Simone de Beauvoir's life, writings, and legacy. To join the Society, please visit: beauvoir.weebly.com. 